\title{
PERBANDINGAN KEPUASAN MAHASISWA TERHADAP KINERJA PEGAWAI SEBELUM DAN SESUDAH PENETAPAN BADAN LAYANAN UMUM (BLU)
}

\author{
Betty Andiyarti \\ Poltekkes Kemenkes Bengkulu
}

\begin{abstract}
Background: The performance-based system of Public Enterprise (BLU) demanding educational institutions is to provide service to the community as a provider of goods or services without seeking profits and in its implementation is based on the principle of efficiency and productivity. The performance of a public Enterprise already refers to the service of the public sector who apply principles (1) simplicity, (2) clarity, (3) certainty of timing, (4) accuracy, (5) security, (6) responsibilities, (7) the completeness of facilities and infrastructure, (8) ease of access, (9) comfortability, (10) discipline, courtesy, and hospitality. In educational institutions, academic performance in the field, laboratory and process of teaching and learning should be able to provide optimal service to students as users of services, in this study, the employee's performance will be discussed on the basis of 6 (six) criteria of employees' performance indicators in terms of quality, quantity, timeliness, effectiveness, independence, commitment and work.

The purpose of the research: to see the performance of the employees of the Administration section of the Lab Manager, academic and lecturer at performance learning process in providing services to students as users of services in educational institutions.

Method: This research uses qualitative type of approach. In this research will provide information about two different situations, namely the experience of the past and experience at this time, so it can be known to the satisfaction of the students against the performance of the employee before and after implementation of Public Enterprise (BLU).

Results: Prior to the determine of the employee's performance in BLU provides services not yet optimal, officers have not provided accurate information to students, not working in accordance with the given service time, however after the determine of the employee's performance in BLU provides services to students and employees are already increasing duties in accordance with the auth respectively.

Conclusion: The implementation of public Enterprise (BLU) can improve the performance of employees in terms of service so that it can give satisfaction to the students as a user of services in educational institutions.
\end{abstract}

Keywords: public service, performance, satisfaction

\section{ABSTRAK}

Latar belakang: Sistem Kinerja Berbasis Badan Layanan Umum (BLU) menuntut Institusi Pendidikan yaitu untuk memberikan pelayanan kepada masyarakat sebagai penyedia barang atau jasa tanpa mencari keuntungan dan dalam pelaksanaannya didasarkan pada prinsip efisiensi dan produktifitas. Kinerja Badan Layanan Umum sudah mengacu pada pelayanan sektor publik yang menerapkan prinsip (1) kesederhanaan, (2) kejelasan, (3) kepastian waktu, (4) akurasi, (5) keamanan, (6) tanggung jawab, (7) kelengkapan sarana dan prasarana, (8) kemudahan akses, (9) kenyamanan, (10) kedisiplinan, kesopanan, dan keramahan. Dalam Institusi pendidikan, kinerja pelayanan dibidang akademik, laboratorium dan proses belajar mengajar harus bisa memberikan pelayanan yang optimal kepada mahasiswa sebagai pengguna jasa layanan, dalam penelitian ini kinerja pegawai tersebut akan dibahas berdasarkan 6 (enam) kriteria indikator kinerja pegawai yaitu dari segi kualitas, kuantitas, ketepatan waktu, efektifitas, kemandirian, dan komitmen kerja. Penelitian ini

korespondensi: abeth.dvd@gmail.com 
bertujuan untuk melihat kinerja pegawai bagian administrasi akademik, pengelola laboratorium dan kinerja dosen pada proses pembelajaran dalam memberikan pelayanannya kepada mahasiswa sebagai pengguna jasa layanan di institusi pendidikan.

Metode: Penelitian ini menggunakan pendekatan eksploratif dengan metode kualitatif. Dalam penelitian ini akan memberikan informasi mengenai dua situasi yang berbeda yaitu pengalaman masa lampau dan pengalaman pada saat ini, sehingga dapat diketahui kepuasan mahasiswa terhadap kinerja pegawai sebelum dan sesudah penetapan Badan Layanan Umum (BLU).

Hasil: Sebelum penetapan BLU kinerja pegawai dalam memberikan pelayanan belum optimal, petugas belum memberikan infomasi yang akurat kepada mahasiswa, belum bekerja sesuai dengan waktu pelayanan yang diberikan, namun setelah penetapan BLU kinerja pegawai dalam memberikan pelayanan kepada mahasiswa semakin meningkat dan pegawai sudah menjalankan tugas sesuai dengan tupoksi masing-masing.

Kesimpulan: Penetapan Badan Layanan Umum (BLU) dapat meningkatkan kinerja pegawai dalam hal pelayanan sehingga dapat memberikan kepuasan kepada mahasiswa sebagai pengguna jasa layanan di Institusi Pendidikan

Kata kunci: pelayanan publik, kinerja, kepuasan

\section{PENDAHULUAN}

Pengelolaan sumber daya manusia dalam hal ini adalah pegawai merupakan kebutuhan yang mendesak dalam menghasilkan pegawai yang berkualitas sehingga pegawai harus dimanaj secara optimal agar sesuai dengan kebutuhan dan bisa menjadi aset organisasi dalam memberikan pelayanan yang tidak terlepas dari kinerja yang dimilikinya. Sesuai dengan gerakan Reinventing Government, bahwa kinerja tidak lagi diukur dengan berapa besarnya input dan bagaimana prosedur yang ditempuh untuk mencapai output sebagaimana yang dianut selama ini, tetapi dengan mengutamakan hasil akhir yang benar-benar dirasakan pelangggan. ${ }^{1}$

Rendahnya kualitas pelayanan dan banyaknya keluhan mahasiswa, mulai dari pelayanan yang tidak ramah, kurangnya informasi yang diperoleh, lambatnya pelayanan akademik, pengaturan jadwal praktek laboratorium yang tidak sesuai sehingga penggunaannya tidak efektif, untuk itu perlu adanya pelayanan yang berorientasi pada pelanggan dalam hal membantu dan melayani pelanggan baik internal maupun eksternal untuk memenuhi kebutuhan mereka, karena pelayanan adalah kunci keberhasilan dalam berbagai usaha atau kegiatan yang bersifat jasa. ${ }^{2}$

Penerapan Badan Layanan Umum (BLU) telah membuka kesempatan secara luas bagi Institusi
Pendidikan untuk mengoptimalkan kinerja pegawai dalam memberikan pelayanan yang lebih baik bagi mahasiswa. Sejalan dengan konsep Badan Layanan Umum (BLU) yang menerapkan pelayanan publik sehingga diharapkan kepada pegawai untuk dapat meningkatkan kinerjanya dalam hal memberikan kepuasan kepada mahasiswa sebagai pengguna jasa layanan publik di institusi pendidikan.

\section{METODE}

Penelitian ini menggunakan metode penelitian kualitatif, dalam penelitian ini memberikan informasi mengenai dua situasi yang berbeda yaitu pengalaman masa lampau dan pengalaman pada saat ini, sehingga diketahui bagaimana kinerja pegawai serta kinerja dosen sebelum dan sesudah penetapan Badan Layanan Umum (BLU) dalam memberikan kepuasan kepada mahasiswa sebagai pengguna jasa layanan publik. Untuk itu dapat disimpulkan bahwa penelitian kualitatif berusaha membangun makna tentang suatu fenomena berdasarkan pandanganpandangan dari para partisipan. ${ }^{3}$ Responden telah mewakili masing-masing jurusan dan untuk menguji keabsahan data dilakukan triangulasi informan penunjang yang mewakili bagian administrasi akademik, laboratorium dan tenaga pengajar. 


\section{HASIL DAN PEMBAHASAN}

Sebelum adanya penetapan Badan Layanan Umum (BLU) organisasi pemerintah disebut Satuan Kerja (satker) dimana kegiatan penyelenggaraannya berdasarkan input dan melaksanakan tugasnya sesuai dengan arahan dari pemerintah. Setelah penetapan kinerja berbasis Badan Layanan Umum (BLU) banyak perubahan yang terjadi antara lain: 1) perubahan struktur organisasi; 2) laporan keuangan; 3) peningkatan pelayanan publik; 4) peningkatan kinerja pegawai; dan 5) menciptakan peluang usaha untuk membantu meningkatkan keuangan instansi, penetapan badan layanan tersebut telah merubah sistem kinerja pegawai dari sistem birokrasi ke sistem berbasis kinerja sehingga menutut setiap pegawai untuk meningkatkan kinerjanya terutama dalam memberikan pelayanan kepada pengguna jasa layanan publik dalam hal ini adalah mahasiswa.

Kinerja Pegawai Sebelum dan Setelah Penetapan Badan Layanan Umum (BLU) dalam penelitian ini dibahas tentang pelayanan petugas administrasi akademik, laboratorium dan dosen. Pelayanan tersebut diuraikan dalam 6 indikator ktriteria kinerja pegawai diantaranya kualitas, kuantitas, efektifitas, kemandirian dan komitmen kerja. ${ }^{4}$

\section{Administrasi Akademik}

a. Kualitas

Sebelum penetapan BLU prosedur pelayanan administrasi akademik belum dilakukan secara optimal, mahasiswa mengungkapkan bahwa prosedur pelayanan sebelum BLU tidak dijelaskan secara langsung oleh mahasiswa, setelah penetapan BLU petugas administrasi akademik mulai memberikan penjelasan sehingga mahasiswa selalu memperoleh infomasi yang akurat.

Sama halnya seperti yang disampaikan oleh salah satu petugas administrasi berikut:

"...Kalo dulu sih sebenarnya memang ditempel di depan ruangan ya, karena untuk mempermudah mahasiswa aja maksudnya kalo kita lagi nggak ditempat mahasiswa masih bisa liat-liat syaratnya apa saja..." (Adm, B9-12,H1) ".....sekarang ya dijelaskan walaupun tetap kita ditempelin juga didepan, namanya juga mahasiswa kadang udah ditempelin syaratnya dipapan pengumuman masih ada juga yang mau mereka tanyakan, apalagi sejak kita sudah menerapkan BLU prosesnyakan juga berbeda, keluar masuk uang juga beda-beda jadi kalo salah rekening bisa repot nanti orang keuangannya jadi sekarang mereka harus catat nomor rekening untuk bayar uang SPP biar nggak salah pos nanti, kalo dulukan rekening yang ada itu sudah tercantum di blanko Bank BTN jadi mereka tinggal menuliskan apa saja yang mau di bayarkan" (Adm, B12-23,H1)

b. Kuantitas

Kuantitas merupakan jumlah yang dihasilkan atau ukuran banyaknya pekerjaan yang dapat diselesaikan dalam batas waktu tertentu. Untuk pengurusan secara kolektif setiap jurusan sudah berjalan dengan baik karena dibantu oleh wali tingkat yang dipilih oleh Ketua Jurusan dan ditetapkan dengan surat tugas.

c. Ketepatan waktu

Ketepatan waktu merupakan kemampuan seorang individu menyelesaikan suatu pekerjaan dalam waktu yang telah ditentukan dan kemampuan seorang individu dalam memberikan pelayanan sesuai dengan jam pelayanan yang telah disepakati sebelumnya. Hal tersebut sejalan dengan hasil observasi peneliti bahwa petugas selalu berada ditempat dan jika keluar ruangan untuk suatu keperluan, selalu ada tenaga kontrak yang menggantikan posisi sementara apabila ada mahasiswa yang membutuhkan informasi (Adm,H2,J1,08.20-09.15).

\section{d. Efektifitas}

Efektifitas disini bagaimana seorang pegawai mampu menggunakan fasilitas kantor dalam membantu penyelesaian pekerjaan dengan mudah dan cepat sehingga pekerjaan dapat 
terselesaikan dengan baik dari segi waktu maupun hasil kerja. Menurut mahasiswa sebelum dan sesudah BLU sudah banyak pegawai yang memanfaatkan fasilitas kantor seperti penggunaan laptop, komputer maupun infocus, seperti kutipan salah satu mahasiswa berikut dan dibuktikan dengan inventaris kantor yang memadahi;

“...sudah bunda, dari dulu juga sudah banyak komputer tiap ruangan, ditambah sekarang udah pake laptop semua dosen dan pegawainya, kan nggak mungkin nggak dipake bunda, heheee..." (Mh2,B59-62,H2)

e. Kemandirian

Kemandirian disini yaitu kemampuan pegawai dalam menjalankan pekerjaan sesuai dengan tugas dan fungsinya berarti pegawai tersebut merupakan pegawai yang mandiri. Berusaha mandiri dalam melakukan pekerjaannya tanpa harus meminta pertolongan dari atasan maupun rekan kerja jika memerlukan atau menemukan masalah dalam bekerja.

Menurut mahasiswa sebelum penetapan BLU petugas belum mengerjakan pekerjaannya sesuai dengan tupoksinya, namun seiring berjalannya waktu pegawai sudah mampu menjalankan pekerjaannya sesuai dengan tupoksi yang diberikan. Sesuai dengan ungkapan petugas administrasi bahwa petugas pernah memanfaatkan mahasiswa dalam membantu tupoksinya dan keadaan tersebut terpaksa dilakukan kerena terlalu banyaknya pekerjaan yang harus dilakukan pada saat itu:

“...pernah, tapi dulu ya..saya pernah minta bantuan mahasiswa tapi itu sebenarnya udah terlalu banyak yang mau dikerjakan dan semuanya mau cepat, kita kaki tangan aja cuma dua gimana mau cepat ya hehehe... terkadang kasihan juga mahasiswa jadi kena marah di direktoratnya karena kita nyuruh dia buat bantu tugas kita". (Adm,B54-61,H2)
"Yaaa...sekarang ngantar sendiri mbak, mau gimana lagi karena udah tugas kita, kalo nggak dikerjakan kita juga yang kena teguran" (Adm,B52-54,H2)

f. Komitmen kerja

Sebelum dan setelah penetapan BLU indikator tersebut sudah berjalan dengan baik, karena sebagian besar petugas sangat ramah kepada mahasiswa dan petugas juga berpenampilan rapi serta menarik, hal tersebut diperkuat dengan Surat Edaran Kementerian Kesehatan RI Nomor: HK.03.03/V/578/2014 tentang Penggunaan Pakaian Kerja di Lingkungan Kementerian Kesehatan dan Surat Direktur tentang penetapan jam kerja, izin tidak masuk kerja, pemberian cuti pegawai dan penggunaan pakaian seragam.

Kinerja pegawai bagian akademik sangat penting dalam memberikan pelayanan kepada mahasiswa karena salah satu bentuk pelayanan dari perguruan tinggi adalah pelayanan administrasi akademik. Administrasi akademik sendiri merupakan suatu rangkaian kegiatan atau keseluruhan proses pengendalian usaha kerjasama sejumlahoranguntuk mencapaisuatu tujuan yang telah dirumuskan secara berencana dan sistematis yang diselenggarakan dalam lingkungan pendidikan formal. ${ }^{5}$

Kinerja pelayanan administrasi akademik sangat berpengaruh terhadap kepuasan mahasiswa, untuk itu sebaiknya pegawai dapat memberikan pelayanan yang lebih baik, selalu siap dalam membantu mahasiswa melakukan urusan administrasi akademik, berpenampilan yang rapi serta bersikap ramah, pegawai yang mampu berkomunikasi baik dengan mahasiswa terkait dengan kegiatan administrasi akademik maka mahasiswa akan merasa lebih aman dalam melakukan urusan akademik sehingga mahasiswa merasa semua kebutuhan yang diinginkan mampu terpenuhi dengan maksimal. ${ }^{6}$ 


\section{Laboratorium}

Laboratorium merupakan unit penunjang akademik pada lembaga pendidikan, berupa ruang tertutup atau terbuka yang bersifat permanen atau bergerak, dikelola secara sistematis untuk kegiatan pengujian, dan/ atau produksi dalam skala terbatas dengan menggunakan peralatan/bahan berdasarkan metode keilmuan tertentu, dalam rangka pelaksanaan pendidikan atau pengabdian

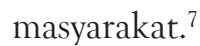

a. Kualitas

Kualitas disini bagaimana seorang petugas mampu melakukan pekerjaan sesuai dengan apa yang diperintahkan berdasarkan input yaitu menjaga semua peralatan di laboratorium sehingga kegiatan laboratorium dapat berjalan dengan baik dan lancar. Menurut mahasiswa semua peralatan yang ada di laboratorium sudah bagus dan sesuai dengan standar.

Sejalan dengan apa yang telah dilakukan petugas di laboratorium bahwa untuk mencapai target kegiatan di laboratorium petugas berusaha menyediakan peralatan sesuai dengan Kepmenkes RI Nomor HK.03.05/IV/14354.1/2010 tentang standar laboratorium pendidikan tenaga kesehatan sehingga mahasiswa lebih mudah mempraktekkan kegiatannya pada saat di lapangan.

b. Kuantitas

Kuantitas merupakan jumlah/volume pekerjaan yang dapat diselesaikan dalam suatu waktu. Untuk pelayanan laboratorium kuantitas disini merupakan kesesuaian jumlah/volume peralatan yang diberikan petugas kepada mahasiswa untuk kegiatan praktek di laboratorium.

Ketidaksesuaian jumlah/volume antara peralatan yang dipinjam dengan peralatan yang diberikan oleh petugas membuat mahasiswa menjadi tidak fokus dalam menjalani kegiatan praktek di laboratorium karena mahasiswa harus berusaha mencari kekurangan peralatan tersebut. Sebelum dan setelah BLU masih ada sebagian jurusan yang mahasiswanya selalu mengeluh tentang kurangnya jumlah peralatan yang ada dilaboratorium. Hal tersebut sejalan dengan apa yang diutarakan oleh salah satu petugas di laboratorium:

"...Kalo dulu sebenarnya cukup sih mbak terkadang mahasiswa kalo praktek itu sering berbarengan mereka biasanya pinjam alat juga sama jadi alat kita kurang nah sekarang alat kita itu banyak yang sudah rusak udah nggak bisa dimanfaatkan lagi (Lab, B62-68,H2).

c. Ketepatan Waktu

Ketepatan waktu dalam pelayanan menyangkut ketepatan dalam memberikan pelayanan kepada mahasiswa sesuai dengan waktu yang telah disepakati. Sebelum dan setelah BLU petugas sudah berusaha memberikan pelayanan yang terbaik untuk mahasiswa, pelayanan yang baik tersebut juga dirasakan sebagian besar mahasiswa bahwa petugas selalu melayani mahasiswa sesuai dengan jam pelayanan. Hal ini juga terlihat dari jumlah absensi pegawai laboratorium yang selalu dan pulang tepat waktu.

\section{d. Efektifitas}

Efektifitas disini petugas mampu memberikan pelayanan dengan sigap dan membantu mahasiwa praktek pada saat menemukan kendala pada peralatan yang di laboratorium serta mampu mengatur jadwal laboratorium dengan baik. Sebelum dan setelah BLU petugas sudah berusaha membantu kegiatan mahasiswa saat praktek di laboratorium dengan mendatangi mahasiswa keruangan praktek dan menjelaskan cara penggunaan alatnya.

Namun ada hal yang belum mampu petugas lakukan pada saat sebelum BLU yaitu pengaturan jadwal praktek, menurut mahasiswa mereka sering mengalami bentrok jadwal dengan kelas lain sehingga 
pihak petugas menyarankan untuk menjadwal ulang praktikum pada saat itu. Sejalan dengan ungkapan salah satu petugas laboratorium pada kutipan berikut:

"Dulu sering sekali bentrok jadwal...., sekarang sih sudah nggak lagi, kita sudah tekankan dari awal kalo mau merubah jadwal lab, bagian lab harus dikasih tau jadi kita bisa menyesuaikan dengan jadwal yang sudah kita buat dari awal supaya anak-anak bisa belajar juga dengan tenang, nggak sibuk dengan mengatur jadwal terus" (Lab,B18-27,H1)

Untuk mengantisipasi keadaan tersebut, petugas sudah mencantumkannya pada tata tertib laboratorium terpadu pada point 2 yaitu "penggunaan laboratorium harus sesuai dengan jadwal yang sudah ditetapkan, apabila terjadi pergeseran jadwal, pihak jurusan harus melakukan konfirmasi dengan pihak laboratorium untuk disesuaikan kembali jadwal penggunaan laboratorium berikutnya."

e. Kemandirian

Kemandirian disini menunjukkan bahwa petugas mampu mengatasi masalah-masalah yang ada di laboratorium, melaksanakan kegiatan yang berkaitan dengan tupoksinya tanpa meminta bantuan kepada orang lain. Sebagian besar petugas pada saat ini sudah menjalankan tugasnya sesuai dengan tupoksi masing-masing, menurut mahasiswa petugas ikut membantu pengoperasian alat, menata ruangan dan menyusun alat dengan rapi.

f. Komitmen Kerja

Komitmen kerja seorang pegawai selain mempunyai percaya diri juga mempunyai keinginan yang baik dan mampu bekerjasama. Dalam memberikan pelayanan kepada mahasiswa, apabila petugas tidak memiliki komitmen yang baik maka petugas bisa saja memberikan efek yang kurang baik juga terhadap mahasiswa sebagai pengguna jasa layanan di Poltekkes. Pada saat ini, petugas selalu berusaha bekerjasama yang baik dengan mahasiswa dan selalu menggunakan seragam sesuai dengan ketentuan.

Tata tertib laboratorium dibuat untuk ditaati bersama, apabila dilanggar akan mendapatkan sangsi hal tersebut juga sudah dijalankan petugas dengan baik sesuai dengan kutipan wawancara berikut:

"Dari dulu sebenarnya kita sudah menerapkan sangsi sama semua mahasiswa disini tujuan diberikannya juga bukan untuk menakuti atau membuat mahasiswa jadi males datang ke lab ya, supaya mereka lebih menjaga barang-barang di lab sama mentaati peraturan aja..." (Lab, B81-86,H2)

Namun ada beberapa keadaan dimana teguran yang didapat oleh mahasiswa tidak ada didalam peraturan yang sudah disepakati oleh seluruh petugas di laboratorium:

".....kayak di lab itukan ada tata tertib tapi semuakan nggak dicantumkan bunda kayak dilarang duduk di bed, ......temen itu cuma nyandar tapi kalo dilihat dari luar kayak duduk gitu bunda, nah langsung dipanggil terus buat surat pernyataan bunda nggak ditegur dulu,..." (Mh1,B273-285,H6)

Setiap pemberian sangsi baik kehilangan, kerusakan atau pelanggaran tata tertib yang ada dilabortorium selalu disertakan dengan berita acara kehilangan maupun surat pernyataan dari mahasiswa. Selain penerapan sangsi, dalam memberikan pelayanan dilaboratorium petugas harus mampu memenuhi kebutuhan mahasiswa sehingga mahasiswa mampu memberikan yang terbaik pada saat praktek di rumah sakit, puskesmas maupun pelayanan kesehatan lainnya. Pelayanan laboratorium yang ideal akan memperlihatkan bahwa eksistensi laboratorium sangat dibutuhkan 
sebagai tempat untuk mempraktekkan teori atau bahkan mengembangkan ilmu pengetahuan, bukan hanya sebagai pengugur kewajiban memprogram mata kuliah. Lingkungan yang selalu bersifat akademis harus menjadi warna dalam laboratorium tersebut, hal ini akan menciptakan budaya berfikir akademis yang akan menjadi karakteristik mahasiswa bahkan setelah lulus nantinya. ${ }^{8}$

\section{Dosen (Proses Belajar Mengajar)}

Berdasarkan hasil penelitian tentang kinerja dosen dalam hal ini berkaitan dengan proses belajar mengajar dikelas atau pada saat praktek, sebelum maupun setelah penetapan BLU mahasiswa merasa semua proses sudah berjalan dengan baik, dari segi kualitas, kuantitas, ketepatan waktu, efektifitas, kemandirian dan komitmen kerja menurut mereka setiap dosen sudah menguasai semua materi, memenuhi jumlah pertemuan setiap mata kuliah, pemberian materi sesuai dengan jadwal, mampu memanfaatkan semua fasilitas yang ada termasuk dilaboratorium serta mandiri dalam membuat materi dan Satuan Acara Pembelajaran (SAP), untuk komitmen kerja sebagian besar dosen sudah menyampaikan materi sesuai dengan modul awal yang diberikan. Hal tersebut dapat dilihat dari adanya Rencana Pelaksanaan Pembelajara (RPP), agenda perkuliahan, absensi sampai dengan materi yang akan disampaikan oleh tenaga pengajar dalam proses belajar mengajar baik dikelas maupun pada saat praktikum.

Pada prinsipnya proses pembelajaran sangat mendukung proses interaksi edukatif untuk mencapai tujuan tertentu sehingga diharapkan seorang tenaga pengajar mampu mengolah sumber-sumber pada saat belajar agar mahasiswa merasa nyaman, memiliki kepuasan sendiri pada saat belajar sehingga mahasiswa dapat menyerap ilmu lebih banyakguna memberikan pengalaman pada saat mereka berada dilapangan, sehingga terdapat pengaruh yang signifikan dan positif antara proses pembelajaran dan kepuasan mahasiswa. ${ }^{9}$
Dari hasil penelitian terdapat perbedaan kinerja pegawai sebelum dan sesudah penetapan Badan Layanan Umum (BLU) hal ini memberi isyarat bahwa dengan adanya penetapan Badan Layanan Umum (BLU) memungkinkan pegawai bekerja sesuai dengan tupoksinya dan merubah pola pikir pegawai sehingga dapat memberikan pelayanan terbaik kepada mahasiswa sebagai pengguna jasa layanan publik di Institusi Pendidikan. Dari kinerja petugas akademik sebelum dan sesudah penetapan Badan Layanan Umum (BLU) terlihat banyak perubahan diantaranya petugas belum memberikan informasi yang akurat, prosedur pelayanan belum dilakukan secara oprimal karena mahasiswa tidak diberikan penjelasan secara langsung dan petugas masih memanfaatkan jasa mahasiswa dalam menjalankan tugasnya. Setelah penetapan BLU petugas administrasi akademik mulai memberikan penjelasan sehingga mahasiswa selalu memperoleh informasi yang akurat, petugas telah menjalankan tugas sesuai dengan tupoksinya sehingga mahasiswa dapat fokus dalam proses belajar mengajar. Dengan demikian terlihat bahwa terdapat perbedaan yang signifikan antara kinerja akademik dalam melayani mahasiswa, pada hakekatnya mahasiswa yang memperoleh pelayanan akademiknya baik dapat mengembangkan kemampuan belajar dan meningkatkan prestasi. ${ }^{10}$

Kondisi pelayanan di laboratorium pada saat sebelum dan setelah BLU juga mengalami perubahan, diantaranya petugas selalu memberikan penjelasan tentang prosedur peminjaman, pengembalian maupun denda, petugas selalu memberikan pelayanan sesuai jadwal pelayanan, menyediakan peralatan laboratorium sesuai standar Pusdiknakes, namun setelah BLU masih ada beberapa kegiatan yang belum dapat dipenuhi oleh petugas diantaranya; mahasiswa masih mendapatkan teguran dan sangsi yang mereka tidak ketahui karena kesalahan tersebut tidak terdapat dalam tata tertib yang menjadi komitmen bersama antara petugas dan mahasiswa disamping itu petugas belum mampu menyediakan jumlah peralatan sesuai dengan kebutuhan pada saat praktikum. Peningkatan bukti fisik termasuk kondisi peralatan pada prinsipnya akan berdampak pada peningkatan pelayanan dan menghasilkan 
peningkatan fasilitas kesehatan. ${ }^{11}$ Dalam memberikan pelayanan dilaboratorium petugas harus mampu memenuhi kebutuhan mahasiswa pada saat praktek sehingga mahasiswa mampu memberikan yang terbaik pada saat praktek di rumah sakit, puskesmas maupun pelayanan kesehatan lainnya.

Untuk kinerja dosen dalam proses belajar mengajar sebelum maupun sesudah penetapan BLU berjalan dengan baik dan sesuai dengan tupoksinya. Menurut mahasiswa, dosen sangat menguasai materi pembelajaran, telah memenuhi jumlah pertemuan setiap mata kuliah, mampu memanfaatkan semua fasilitas, mandiri dalam membuat materi maupun Rencana Pelaksanaan Pembelajaran (RPP) serta selalu memberikan feedback setiap tugas yang dikerjakan. Dosen sebagai fasilitator diharapkan mampu mengolah sumber-sumber pada saat belajar agar mahasiswa dapat mengerti, memahami pengetahuan (aspek kognitif), mampu mengekspresikan dalam sikap (aspek efektif) dan keterampilan (aspek psikomotorik) di lapangan serta dapat menyerap ilmu lebih banyak guna memberikan pengalaman pada saat mereka bekerja, sehingga ada pengaruh yang signifikan dan positif antara proses pembelajaran dan kepuasan mahasiswa..$^{12}$ Selain itu tingkat kepuasan yang tinggi dengan lingkungan belajar sangat diperlukan untuk memikul tanggung jawab dalam belajar sehingga kinerja dosen dapat memberikan kontribusi krusial dengan persepsi subjektif belajar mahasiswa. ${ }^{13}$

Memberikan pelayanan yang prima merupakan tujuan dari instansi yang menerapkan kinerja berbasis Badan Layanan Umum (BLU) agar penetapan status BLU dapat bertahan lama pada Instansi tersebut. Ada beberapa keistimewaan dari BLU dari instansi satuan kerja pemerintah lain, diantaranya: 1) fleksibilitas dalam pengelolaan keuangan; 2) pengangkatan tenaga profesional non PNS dalam membantu pengelolaan keuangan BLU; 3) keleluasaan dalam menjalankan unit usaha/bisnis untuk meningkatkan dan memenuhi kebutuhan instansi; dan 4) diberikan honor diluar gaji dan tunjangan lain dari dana yang dikelola oleh BLU, sehingga pegawai juga dituntut untuk meningkatkan kinerjanya, pegawai yang memiliki kinerja tinggi biasanya menunjukan loyalitas dan kemampuan profesionalnya. ${ }^{14}$ Dengan diberikannya keleluasaan menjalankan usaha maka pegawai dituntut harus selalu aktif dan menciptakan inovasi baru agar Penerapan BLU ini dapat berjalan dengan baik dan berkelanjutan. Perkembangan usaha dalam organisasi sektor publik dapat membantu peningkatan penghasilan, masalah ekonomi dan peningkatan usaha dalam pemenuhan permintaan pelanggan yang dapat dipetanggung jawabkan lebih lanjut. ${ }^{15}$

Dampak lain yang mungkin akan dialami oleh Institusi Pendidikan yang baru menerapkan sistem berbasis kinerja Badan Layanan Umum adalah tidak mudah merubah secara langsung pegawai yang tidak dapat menerima perubahan dari organisasi itu sendiri, sehingga perlu adanya suatu kelompok/ orang yang bertanggung jawab untuk mengubah sikap yang ada para orang tertentu pada suatu sistem tertentu. ${ }^{16}$

Penerapan sistem berbasis kinerja Badan Layanan Umum (BLU) ini sangat baik apabila diterapkan disemua instansi Pemerintah, dengan adanya perubahan pola pikir maka setiap pegawai akan meningkatkan kinerjanya, bekerja sesuai dengan tupoksi yang diberikan, menciptakan peluang usaha baru yang juga dapat meningkatkan keuangan instansi dan meningkatkan kesejahteraan bagi pegawai dengan memberikan pendapatan lain diluar gaji oleh pimpinan dari pengelola layanan usaha yang dijalani. Keberhasilan pelaksanaan pelayanan publik akan memperoleh dampak secara langsung terhadap peningkatan kinerja dan peningkatan keuangan. ${ }^{17}$

\section{KESIMPULAN}

Dengan penetapan Badan Layanan Umum (BLU) di Institusi Pendidikan telah meningkatkan rasa tanggung jawab kepada semua pegawai untuk memberikan perhatiannya kepada mahasiswa, sebelum penetapan BLU petugas belum melakukan pelayanannya secara optimal dan belum mandiri dalam menjalankan tugasnya sehingga tidak dapat menjalankan tupoksinya dengan baik, namun setelah penetapan Badan Layanan Umum (BLU) ada peningkatan kinerja pegawai dalam hal pelayanan yang semakin baik, mengarahkan dan menumbuhkan rasa tanggungjawab bagian pelayanan bidang akademik, bekerja sesuai tupoksi 
yang diberikan sehingga dapat membantu Instansi BLU yang berkelanjutan.

Ada beberapa kinerja petugas laboratorium yang belum memberikan pelayanan yang terbaik bagi mahasiswa diantaranya petugas masih memberikan sangsi diluar tata tertib yang harus dipatuhi dan menjadi komitmen bersama antara mahasiswa dan petugas serta belum terpenuhinya jumlah peralatan yang dibutuhkan mahasiswa pada saat melakukan praktikum, dengan keadaan demikian diharapkan petugas dapat memperjelas point tata tertib dilaboratorium sehingga semua pelanggaran dapat diterapkan sesuai dengan peraturan yang berlaku agar tidak menimbulkan rasa ketidakpuasan terhadap mahasiswa sebagai pengguna barang/jasa layanan di laboratorium dan untuk memenuhi jumlah sarana prasarana, memungkinkan institusi menjalin kerjasama yang lebih banyak dengan pihak ke-3 dalam menjaring dana hibah atau mengumpulkan dana melalui masyarakat sebagai imbalan atas barang/jasa dari layanan yang diberikan

\section{DAFTAR PUSTAKA}

1. Keban. Enam Dimensi Strategis Administrasi Publik; Konsep, Teori, Isu, Yogyakarta: Penerbit Gaya Media; 2008.

2. Leo C. Social Marketing Customer Orientation: A Conceptualization, Typology, and Conceptual Framework. Journal of Nonprofit Eु Public Sector Marketing, 2013;25(1):56-80. Available at: http:// www.tandfonline.com/doi/abs/10.1080/10495142. 2013.759818 [Accessed February 24, 2015].

3. Creswell JW. Research Design ketiga. Qudsy.Z SAifuddin, ed., Yogyakarta: SAGE; 2009.

4. Bernadin HJ, Rusell J. Human Resousce Management : An Experiential Approach Terjemahan. I. Grow-Hill, ed. Jakarta: Pustaka Binaman Presindo; 1993.

5. Daryanto. Administrasi Pendidikan, Jakarta: Rineka Cipta; 2010.
6. Wahyuningsih T, Noviani L, Maret US. Kepuasan Mahasiswa FKIP UNS atas Kualitas Pelayanan Administrasi Akademik. Jurnal Pendidikan Bisnis dan Ekonomi, 2013;1(1).

7. Menteri Pemberdayaan Aparatur Negara. Permenpan No 03 Tahun 2010 Tentang Jabatan Fungsional Pranata Laboratorium Pendidikan dan Angka Kreditnya, Jakarta: Kementerian Pemberdayaan Aparatur Negara; 2010.

8. Masri M, Fauziah I. Analisis Mutu Layanan Laboratorium. Jurnal Chemical, 2011;12:27-35.

9. Mochamad E. Pengaruh Pembelajaran dan Kualitas Pelayanan Terhadap Kepuasan dan Loyalitas Mahasiswa. Jurnal Dinamika Ekonomi dan Bisnis, 2012;9:1-18.

10. Kim M, Han S. Relationships between the MyersBriggs Type Indicator Personality Profiling, Academic Performance and Student Satisfaction in Nursing Students. Journal of Bio-Science and Bio-Technology, 2014;6(6):1-12

11. Siddiqui. Comparison of Services of Public, Private and Foreign Hospital from ThenPerspective of Bangladeshi Patiens. Journal of Health, Population, and Nutrition, 2007;2.

12. Edris M. Pengaruh Pembelajaran dan Kualitas Pelayanan Terhadap Kepuasan dan Loyalitas Mahasiswa. Jurnal Dinamika Ekonomi dan Bisnis, 2012;9:1-18s

13. Lo CC. How Student Satisfaction Factors Affect Perceived Learning. Journal of the Scholarship of Teaching and Learning, 2010;10(1):47-54.

14. Hersey. Managing Human Resources. USA: Mc. Graw Hill; 2005.

15. Sinuany Z. Operations Research in the Public Sector and Nonprofit Organizations; 2014, pp. 1-8.

16. Winardi. Manajemen Perubahan. Jakarta: Kencana; 2004.

17. Murray M. Innovation In The Public Services Management: Case of Slovakia. Journal of Public Procurement, 2015;15(3):317-40. 